\title{
Ecological factors determining the distribution and assemblages of the aquatic Hemiptera (Gerromorpha \& Nepomorpha) in the Segura River basin (Spain)
}

\author{
José Antonio Carbonell*, Cayetano Gutiérrez-Cánovas, Daniel Bruno, Pedro Abellán, Josefa \\ Velasco and Andrés Millán
}

Departamento de Ecología e Hidrología, Facultad de Biología, Universidad de Murcia. Campus Universitario de Espinardo. 30100. Murcia (Spain).

* Corresponding author: joseantonio.carbonell@um.es

Received: 20/10/10

Accepted: 18/2/11

\begin{abstract}
Ecological factors determining the distribution and assemblages of the aquatic Hemiptera (Gerromorpha \& Nepomorpha) in the Segura River basin (Spain)

Although the Segura River basin is located in one of Europe's most arid regions, it features a wide variety of aquatic ecosystems, some of which are rare within the European continent. Assemblages of aquatic Hemiptera and their indicator species in the Segura River basin, as well as the key environmental factors that determine their distribution, were evaluated in this study. Between 1980 and 2010, a total of 38 species of aquatic Hemiptera were collected in 402 sites that have been classified into 12 types of habitats. Aquatic Hemiptera were well-represented among the different habitats and were widely distributed across the entire study area. Relationships between community structure and environmental variables were evaluated using multivariate analyses, including non-parametric multidimensional scaling (NMDS), principal components analysis (PCA) and distance-based redundancy analysis (dbRDA). Results revealed that the distribution of aquatic Hemiptera was influenced primarily by an environmental gradient from lotic and freshwater headwater environments to lentic and highly-mineralised waters in lower river sections. Hence, the lotic/lentic character of the habitat and its conductivity were the most important factors shaping the spatial distribution of the aquatic Hemiptera in the Segura River basin. Additionally, an indicator species analysis (IndVal) revealed four aquatic Hemiptera assemblage types: one was related with lotic headwater environments, a second was associated with rivers and reservoirs, a third was found primarily in lotic saline environments and a fourth transitional assemblage type was associated with microhabitat availability and included species with a widespread distribution. Defining Hemiptera assemblage types statistically, however, was difficult due to the widespread distribution of species caused by high dispersion capability and low microhabitat requirements.
\end{abstract}

Key words: Hemiptera, distribution, assemblages, ecology, Segura river basin, Spain.

\section{RESUMEN}

Factores ecológicos que determinan la distribución y asociaciones de los Hemípteros acuáticos (Gerromorpha \& Nepomorpha) en la Cuenca del Río Segura (España)

La Cuenca del Río Segura (SE España), a pesar de representar una de las áreas más áridas del Mediterráneo occidental, presenta una amplia variedad de ecosistemas acuáticos, algunos de los cuales son raros a nivel europeo. En dichos ecosistemas, englobados en 12 tipos de hábitats, se han registrado un total de 38 especies de hemípteros acuáticos en 402 estaciones de muestreo entre 1980 y 2010. Se trata de un grupo bien representado en los diferentes hábitats tipo y ampliamente distribuido por el área de estudio. Las relaciones entre la estructura de la comunidad y las variables ambientales fueron estudiadas mediante diferentes técnicas de análisis multivariantes. El análisis de escalamiento multidimensional no paramétrico (NMDS), el análisis de componentes principales (PCA) y el análisis de redundancia basado en las distancias (dbRDA) revelaron que la distribución espacial de los hemípteros acuáticos en la cuenca del río Segura sigue un gradiente ambiental desde ambientes lóticos de agua dulce en cabecera hasta ambientes leníticos mineralizados en desembocadura. Por tanto, el tipo de hábitat (lótico o lenítico) y la conductividad son los principales factores determinantes de la distribución de las especies. Finalmente, 
un análisis de especies indicadoras (IndVal) mostró 4 tipos de asociaciones de especies características de diferentes tipos de hábitats: ambientes lóticos de cabecera, ríos y embalses, ambientes leníticos salinos y un último grupo de transición entre los anteriores. A pesar de estos resultados, los análisis estadísticos muestran que es difícil definir grupos para los hemípteros acuáticos debido a que muchas de estas especies presentan una amplia distribución como resultado de su alta capacidad de dispersión y de su baja especificidad de hábitat.

Palabras clave: Hemiptera, distribución, comunidades, ecología, Cuenca del Río Segura, España.

\section{INTRODUCTION}

The southeastern Iberian Peninsula, one of Europe's most arid regions, is comprised of a wide variety of aquatic ecosystems, ranging from freshwater streams, ponds and wetlands to hypersaline streams, saline lagoons and salt-pans (Millán et al., 2006). Although many of these habitats are found throughout Europe, some are unique to this region and host a high number of rare and endemic species (Moreno et al., 1997; Millán et al., 2002; Sánchez-Fernández et al., 2003; Abellán et al., 2005). Long-term human disturbance has lead to marked alterations and spatial reductions in or disappearances of some habitats in the southeastern Iberian Peninsula, especially in aquatic environments (Allan \& Flecker, 1993; Master et al., 1998; Ricciardi \& Rasmussen, 1999; Saunders et al. 2002). Research on the distribution, taxonomy and ecology of aquatic invertebrates in this region, as well as on the ecological factors that shape species assemblages, will enable the design effective conservation strategies for this unique aquatic biota. Understanding the underlying patterns that define variations in aquatic invertebrate diversity is a crucial step in assessing and preventing loss of biodiversity in this region.

In southeastern Iberia, the Segura River basin is environmentally heterogeneous and displays a strong climatic and altitudinal gradient that follows the longitudinal river flow axis from NW to SE. As compared to other Mediterranean regions, the Segura basin is characterised by scarce and unevenly distributed water resources and high hydrological variability, as defined by low amounts of rainfall distributed irregularly over time and space. Additionally, temporary streams, as well as streams and ponds with naturally highmineral water, are frequently found in this area (Vidal-Abarca et al., 1992). The environmental variation is coupled with an anthropogenic disturbance gradient primarily caused by significant organic pollution that is most intense in the lower course sections of the river basin (Millán et al., 1996; Sánchez-Fernández et al., 2003; Gómez et al., 2005; Velasco et al., 2006). All of these environmental factors are hypothesised to significantly affect species distribution and macroinvertebrate assemblages within the basin (Leland \& Fend, 1998, Mellado 2002; 2005).

Hemipteran species are widespread in southern Iberia and inhabit streams, ponds, wetlands and lagoons (Millán et al., 1988; Moreno et al., 1997, Velasco et al., 2006; Mellado et al., 2008; Moreno et al., 2010). Hemipterans are aquatic invertebrates with a high dispersal capacity, and they can withstand a wide range of environmental and anthropogenic conditions (Velasco \& Millán, 1998; Velasco et al., 1990). Whereas aquatic Coleoptera have been widely studied in this region (Millán et al., 1996; 2006; Sánchez-Fernández et al., 2004), less is known about other macroinvertebrate groups, including aquatic Hemiptera. Although faunistic studies (Fuente, 1894; Gómez et al., 1979; Suárez et al., 1983; Millán et al., 1988; Millán et al., 2002; Abellán et al., 2004), indentification keys (Millán et al., 1987) and life cycle studies (Velasco et al., 1990; Barahona et al., 2005) of aquatic Hemiptera have been carried out in this region of the Iberian Peninsula, information about the eco- 
logical factors that determine species distribution and assemblages is lacking.

The goals of this research were to determine which assemblages of aquatic Hemiptera occur in the Segura River basin, identify the indicator species of each assemblage and define the primary environmental factors that affect the distribution of these assemblages. We hypothesised that the spatial distribution of Hemiptera assemblages would reflect the altitudinal and climatic environmental gradients observed across the Segura River basin.

\section{MATERIAL AND METHODS}

\section{Study area}

The Segura River basin is located in the southeastern region of the Iberian Peninsula. The area covers $18870 \mathrm{~km}^{2}$ (Fig. 1) and includes territories from six Spanish provinces, including Murcia, Alicante, Albacete, Jaén, Granada and Almería. Although the region has a Mediterranean climate, several differences in average rainfall and temperature occur from the $\mathrm{NW}$ to the SE of the basin $\left(1000 \mathrm{~mm} /\right.$ year and $10^{\circ} \mathrm{C}$ in the NW to $300 \mathrm{~mm} /$ year and $18^{\circ} \mathrm{C}$ in the SE). The lithology and geology of the region are very complex, as the plains are characterised by an abundance of limestone, Miocene and Triassic marls and volcanic areas, whereas calcites and dolomites are dominant in the mountain headwaters. The landscape ranges from Mediterranean conifer forests in the northwest to arid and semiarid shrublands in the southeastern lowlands.

\section{Biological dataset}

Species data from 1980 to 2010 were obtained from the literature and using field samples collected by the Aquatic Ecology Research Group at the University of Murcia. A total of 402 sites (Fig. 1) were prospected at least twice; the study area was consistently sampled until additional species could no longer be found. Samples were collected using hand nets (pentagonal or triangular, 20 to $30 \mathrm{~cm}$ deep and 0.5 to $1 \mathrm{~mm}$ mesh) and sampling was stratified by all microhabitat types

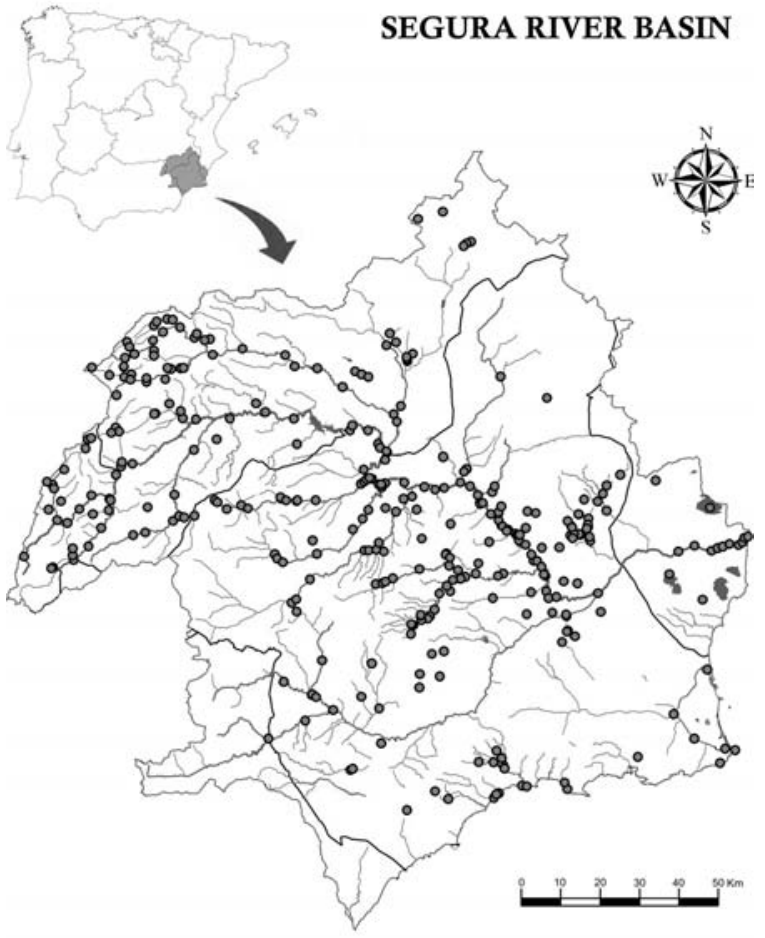

Figure 1. Study area showing the sampling sites. Área de estudio y localidades prospectadas.

considered suitable for aquatic Hemiptera. Samples were preserved in $70 \%$ or pure ethanol and transported to the laboratory for processing and species identification. Species registered on different dates from each sampling site were integrated as cumulative data.

Table 1. Habitat types considered in the study area. The number of sampling sites where each habitat type occurs is also indicated. Hábitats tipo considerados en el área de estudio, indicando el número de localidades en los que aparecen.

\begin{tabular}{lc}
\hline Habitat type & $\mathbf{N}^{\mathbf{0}}$ sites \\
\hline 1. Headwater streams & 60 \\
2. Middle reach streams & 126 \\
3. Rivers & 82 \\
4. Ramblas & 49 \\
5. Springs & 32 \\
6. Irrigation channels & 14 \\
7. Reservoir & 17 \\
8. Artificial pools & 17 \\
9. Pools, ponds & 36 \\
10. Saline wetlands & 23 \\
11. Rice-fields & 8 \\
12. Salt-pans & 8 \\
\hline
\end{tabular}


Table 2. Environmental variables measured in sampled sites. Variables ambientales medidas en las estaciones de mиеstreo.

\begin{tabular}{|c|c|c|c|}
\hline & Environmental variables & Categories/Units & Code \\
\hline \multirow{6}{*}{$\begin{array}{l}\text { Categorical } \\
\text { variables }\end{array}$} & Persistence & 0 (temporary), 1 (spatially intermitent), 2(permanent) & PERS \\
\hline & Current velocity & 0 (standing waters), $1(<15 \mathrm{~cm} / \mathrm{s}), 2(15-50 \mathrm{~cm} / \mathrm{s}), 3(>50 \mathrm{~cm} / \mathrm{s})$ & CVEL \\
\hline & Depth & $0(0-15 \mathrm{~cm}), 1(15-50 \mathrm{~cm}), 2(>50 \mathrm{~cm})$ & DEPT \\
\hline & Macrophyte coverage & 0 (absence), 1(5-10\%), 2(10-30\%), 3(30-70\%), 4(>70\%) & MCOV \\
\hline & Riparian vegetation & 0 (absence), 1(reeds), 2(helophyts), 3(riparian forest) & RIVE \\
\hline & Organic pollution & $\begin{array}{c}0 \text { (clean waters), 1(low eutrophication), 2(medium eutrophication), } \\
\text { 3(high eutrophication) }\end{array}$ & ORPO \\
\hline \multirow{3}{*}{$\begin{array}{l}\text { Quantitative } \\
\text { variables }\end{array}$} & $\mathrm{pH}$ & - & $\mathrm{PH}$ \\
\hline & Altitude & $\mathrm{m}$ & ALT \\
\hline & Conductivity & $\mathrm{mS} / \mathrm{cm}$ & COND \\
\hline
\end{tabular}

\section{Environmental data}

Sites were classified, according to Millán et al. (2002) and Abellán et al. (2005), into 12 habitat types (Table 1) that represented the complete range of aquatic ecosystem diversity present within the study area. Nine environmental variables (six categorical and three quantitative) were measured (Table 2). Water $\mathrm{pH}$ and electric conductivity measurements were collected in the field with standard portable equipment (ECmeter, TetraComR, 325), and altitude was calculated using a GPS device (Garmin 76S). Visual estimates were used to define habitat variables (see Table 2 for classes within each variable), as previously reported (Millán et al., 1996; 2006).

\section{Data analyses}

Both a biological matrix (38 species/402 sites) and an environmental matrix (9 environmen tal variables/402 sites) were created. Sites were classified according to their species composition similarity by hierarchical clustering using the Sorensen dissimilarity method and flexible beta $(\beta=-0.6)$ algorithm (McCune \& Grace, 2002). Indicator species analysis (IndVal, Dufrêne \& Legendre, 1997) identified the key species in each group. This analysis was also used to choose the optimum number of clusters (9999 runs), by using the maximum number of significant indicators and the minimum average $p$-value as objective criteria for pruning a dendrogram (McCune \& Grace, 2002). Alpha was set at 0.0001 to ensure the reliability of the indicator taxa and to retain only the highest indicator values, thus avoiding spurious results. Sites were ordered in relation to their species composition using non-metric multidimensional scaling (NMDS,
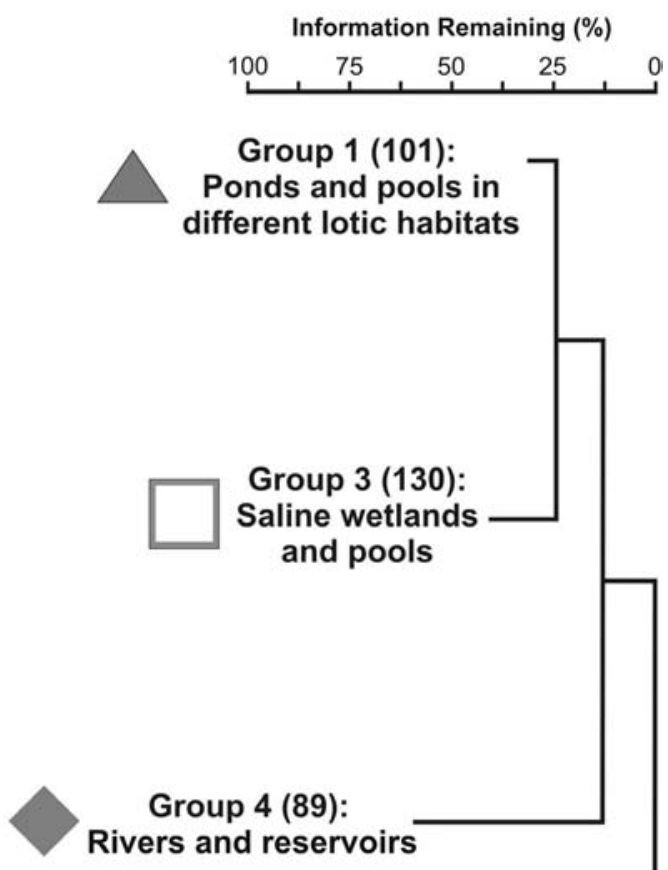

Figure 2. Clustering dendrogram showing the four groups obtained. In parentheses number of sites. Dendrograma de clasificación mostrando los cuatro grupos obtenidos. Número de localidades en paréntesis. 
A

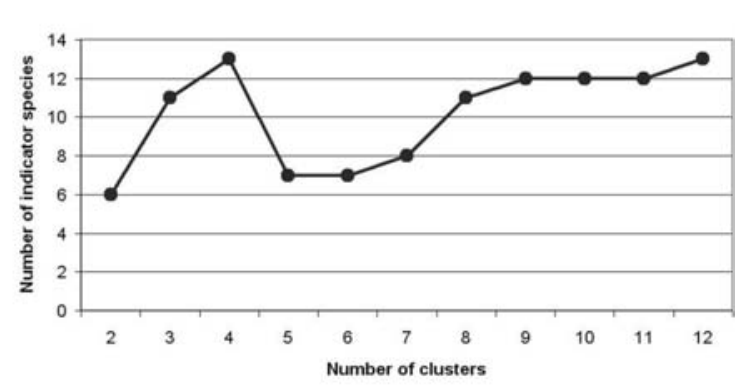

B

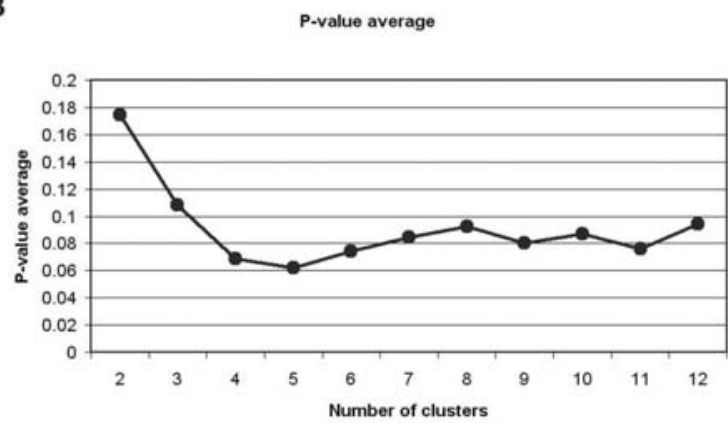

Figure 3. A: Number of indicator species for number of clusters; B: The p-value for number of clusters. A: Número de especies indicadoras en función del número de clusters; $B$ : Media del P-valor en función del número de clusters.

Kruskal \& Wish, 1978) (250 runs). Hierarchical clustering, IndVal and NMDS were performed using PCORD 5 software (McCune \& Grace, 2002). Sampling sites also were ordered by their environmental variables using a principal component analysis (PCA). In the PCA plot, sites were labelled by biotic group to summarise the key environmental features of each assemblage type. Relationships between Hemipteran assemblages and environmental variables were assessed by a distance-based redundancy analysis (dbRDA) limited to three axes. PCA and dbRDA analyses were performed using PRIMER-E software (Clarke \& Gorley, 2006) with the add-on package PERMANOVA+ (Anderson et al., 2008).

\section{RESULTS}

Cluster analysis classified sites into four groups with a cut-off level of $32 \%$ of remaining information (Fig. 2). These groups belonged to the following: (1) pond and pool habitats in various saline and freshwater rivers and streams, (2) headwater streams, (3) saline wetlands and pools and (4) large rivers and reservoirs.

IndVal results with four groups (clusters) had the maximum number of significant indicator species combined with one of the minimum average $p$-values ( $p=0.0001)$ (Fig. 3). Thirteen indicator species were found within the four classified groups (Table 3). Indicator species within Group 1 consisted of Nepa cinerea, Naucoris maculatus, Plea minutissima, Notonecta maculata and Mesovelia vittigera, which inhabit ponds and pools in different lotic habitats with dissimilar water conductivity. Group 2, from headwater streams, consisted of Aquarius najas, Gerris gibbifer, Hydrometra stagnorum and Velia caprai. Anisops sardeus and Sigara selecta were the principal indicator species found in the wetlands and pools in Group 3. Indicator species from rivers and reservoirs in Group 4 included Aquarius cinereus and Micronecta scholtzi. Among these

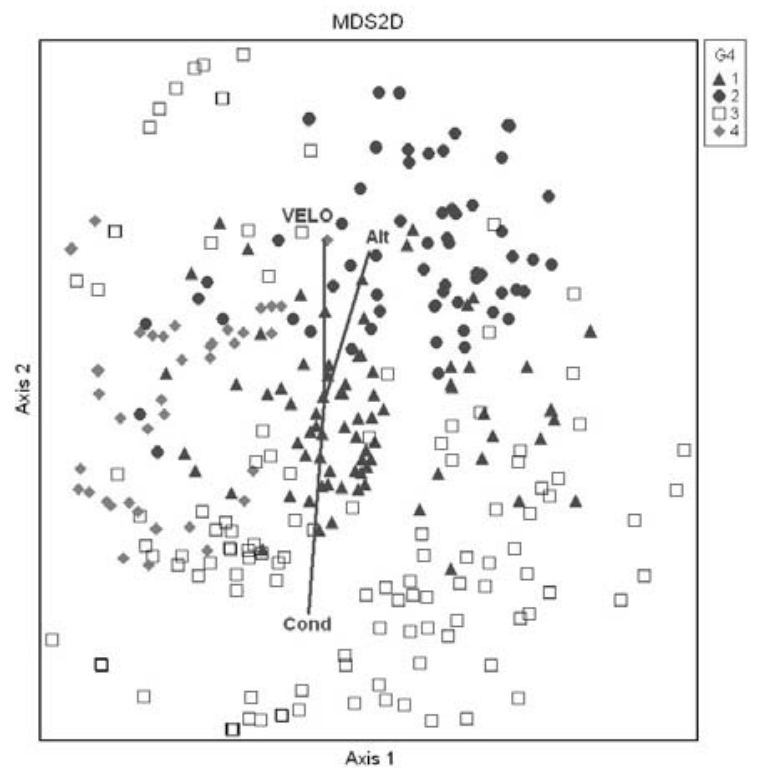

Figure 4. NMDS of sample sites classified by four groups (G4) as defined by the hierarchical clustering (see Figure 2 for the group codes and Table 2 for environmental variable codes). Escalamiento Multidimensional No-Paramétrico de las estaciones de muestreo clasificadas en los 4 grupos (G4) definidos por la Clasificación Jerárquica (ver Figura 2 para los códigos de los grupos y tabla 2 para códigos de las variables ambientales). 
Table 3. IndVal results for the four groups. (*) Indicator species $(p=0.0001)$. IndVal de 4 grupos. (*) Especies indicadoras $(\mathrm{P}-$ valor $=0,0001)$.

\begin{tabular}{|c|c|c|c|}
\hline Species & Group & Indicator value & P-Value \\
\hline Nepa cinerea Linnaeus, $1758^{*}$ & 1 & 38.0 & 0.0001 \\
\hline Naucoris maculatus Fabricius, 1782* & 1 & 33.8 & 0.0001 \\
\hline Notonecta maculata Fabricius, 1794* & 1 & 32.1 & 0.0001 \\
\hline Plea minutissima Leach, 1817* & 1 & 17.2 & 0.0001 \\
\hline Mesovelia vittigera Horváth, $1895^{*}$ & 1 & 11.8 & 0.0001 \\
\hline Microvelia pygmaea (Dufour, 1833) & 1 & 14.5 & 0.0002 \\
\hline Sigara nigrolineata nigrolineata (Fieber, 1848) & 1 & 8.6 & 0.0003 \\
\hline Notonecta viridis Delcourt, 1909 & 1 & 6.1 & 0.0013 \\
\hline Sigara scripta (Rambur, 1840) & 1 & 10.9 & 0.0018 \\
\hline Gerris argentatus Schummel, 1832 & 1 & 4.7 & 0.0038 \\
\hline Gerris thoracicus Schummel, 1832 & 1 & 9.8 & 0.0058 \\
\hline Ochterus marginatus marginatus Latreille, 1804 & 1 & 4.9 & 0.0117 \\
\hline Hebrus pusillus (Fallén, 1807) & 1 & 3.3 & 0.2086 \\
\hline Gerris lacustris (Linnaeus, 1758) & 1 & 1.3 & 0.6404 \\
\hline Velia noualhieri ibericaTamanini, 1968 & 1 & 1.0 & 0.6757 \\
\hline Aquarius najas (de Geer, 1773)* & 2 & 55.2 & 0.0001 \\
\hline Hydrometra stagnorum (Linnaeus, 1758)* & 2 & 20.7 & 0.0001 \\
\hline Velia caprai Tamanini, 1947* & 2 & 18.4 & 0.0001 \\
\hline Gerris gibbifer Schummel, 1832* & 2 & 12.9 & 0.0001 \\
\hline Micronecta minuscula Poison, 1929 & 2 & 9.5 & 0.0002 \\
\hline Aphelocheirus murcius Nieser \& Millán, 1989 & 2 & 4.4 & 0.0084 \\
\hline Notonecta glauca glauca Linnaeus 1758 & 2 & 3.7 & 0.013 \\
\hline Micronecta poweri (Douglas \& Scott 1869) & 2 & 3.0 & 0.0277 \\
\hline Gerris brasili Poisson 1940 & 2 & 6.2 & 0.0402 \\
\hline Notonecta glauca meridionalis Poisson 1926 & 2 & 2.3 & 0.2458 \\
\hline Anisops sardeus Henrrich-Scháffer, 1849* & 3 & 17.3 & 0.0001 \\
\hline Sigara selecta (Fieber, 1848)* & 3 & 16.0 & 0.0001 \\
\hline Sigara lateralis (Leach, 1817) & 3 & 11.6 & 0.0002 \\
\hline Sigara stagnalis stagnalis (Leach, 1817) & 3 & 9.0 & 0.0004 \\
\hline Anisops debilis perplexus Poisson, 1966 & 3 & 8.4 & 0.0038 \\
\hline Paracorixa concinna concinna (Fieber, 1848) & 3 & 3.1 & 0.018 \\
\hline Corixa panzeri (Fieber, 1848) & 3 & 4.0 & 0.0447 \\
\hline Cymatia rogenhoferi (Fieber, 1864) & 3 & 3.3 & 0.1104 \\
\hline Anisops crinitus Brooks, 1951 & 3 & 2.5 & 0.1153 \\
\hline Heliocorisa vermiculata (Puton, 1874) & 3 & 4.5 & 0.1232 \\
\hline Corixa affinis Leach, 1817 & 3 & 1.9 & 0.3051 \\
\hline Aquarius cinereus (Puton, 1869)* & 4 & 48.9 & 0.0001 \\
\hline Micronecta scholtzi (Fieber, 1860)* & 4 & 40.0 & 0.0001 \\
\hline
\end{tabular}

species, A. najas, A. cinereus, M. scholtzi, N. cinerea, N. maculatus and N. maculata displayed the highest indicator values, suggesting that these species were the most habitat-specific.
The ordination of sites classified into four groups within the space defined by the first two axes of the NMDS analysis (30.42\% stress level) indicated highly overlapping areas among 


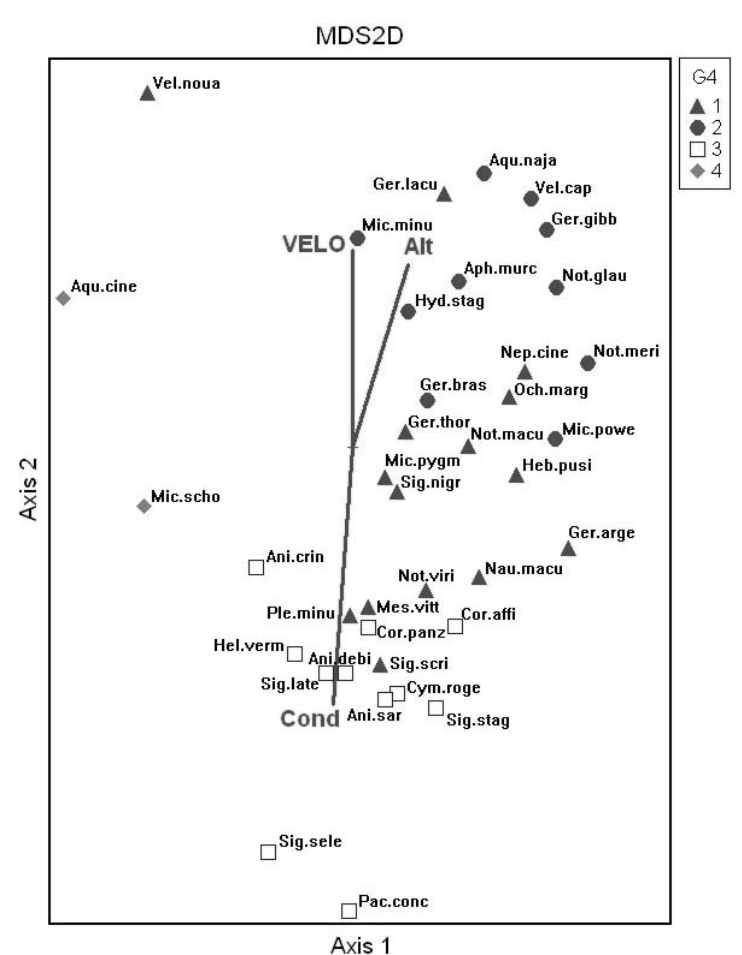

Figure 5. NMDS of species that characterise the four defined groups (G4) by the hierarchical clustering (see Fig. 2 for the group codes and Table 2 for environmental variable codes). Escalamiento Multidimensional No-Paramétrico de las especies que caracterizan los 4 grupos (G4) definidos por la Clasificación Jerárquica (ver Fig. 2 para los códigos de los grupos y Tabla 2 para códigos de las variables ambientales).

the groups. Group 4 demonstrated the greatest amount of clustering, and Group 3 was the most scattered (Fig. 4). Figure 5 illustrates the distribution of species included in each group. The NMDS species ordination had less overlap in relation to site ordination, as species from Group 1 were the most scattered (Fig. 5). Site and species ordination appeared to demonstrate an environmental gradient defined by axis 2 , from lotic and freshwater environments in the upper section of the basin to lentic and high-mineral waters in the lower section. Hence, Groups 2 (headwater streams) and 3 (saline wetlands and pools) were clearly defined along axis 2 , which appeared to split lotic freshwater and saline waters.

The two first axes of the PCA analysis explained $49 \%$ of variation among sites in relation to their environmental features (axis 1: $31.4 \%$ and axis 2: $17.6 \%$ ). Axis 1 displayed an envi- ronmental gradient from freshwater headwaters to mineralised and eutrophic waters in the lower section of Segura River basin. In contrast, axis 2 appeared to be related to a gradient from habitats with deep perennial waters without macrophytes (e.g., impaired rivers and reservoirs) to shallow lentic water bodies with macrophytes (e.g., rice fields and natural ponds and pools) (Fig. 6).

Finally, the dbRDA analysis revealed that the two first axes explained $79.7 \%$ of fitted variation and $13.4 \%$ of total variation. The dbRDA results presented two clear gradients that did not correspond precisely with the two main axes (Fig. 7). The first axe was a result of the environmental gradient that exists from headwaters to aquatic ecosystems in the lower section of the basin. Headwater sites were placed in the upper-right section of the plot (mainly Group 2 ) because these sites display a significant amount of riparian vegetation, rapid current velocities and waters with low mineralisation. Sites become mineralised as altitude and flow decrease, as occurs in the left-side sites (Group 3). The second gradient runs from deep and organically polluted main river sections and reservoirs (Group 4) to unpolluted streams.

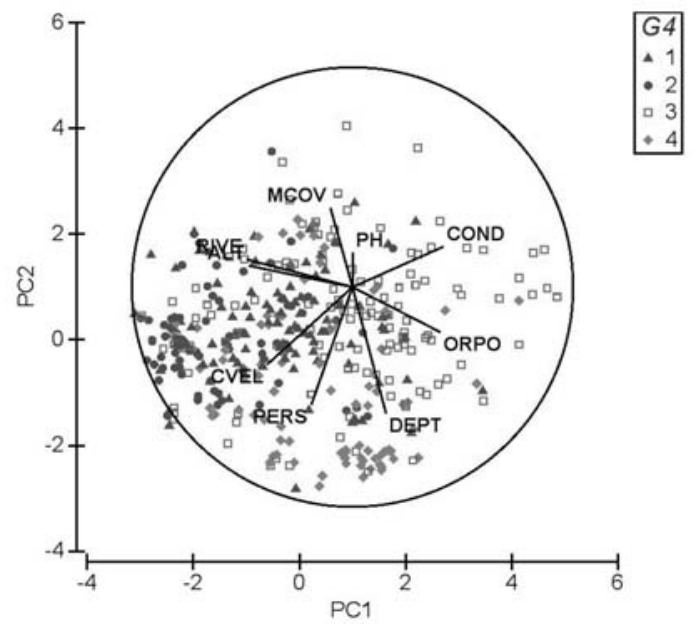

Figure 6. PCA of sample sites classified by four groups (G4) as defined by the hierarchical clustering (see Fig. 2) for the group codes and Table 2 for environmental variable codes). Análisis de Componentes Principales de las estaciones de muestreo clasificadas en 4 grupos (G4) definidos por la Clasificación Jerárquica (ver Fig. 2 para los códigos de los grupos y Tabla 2 para códigos de las variables ambientales). 


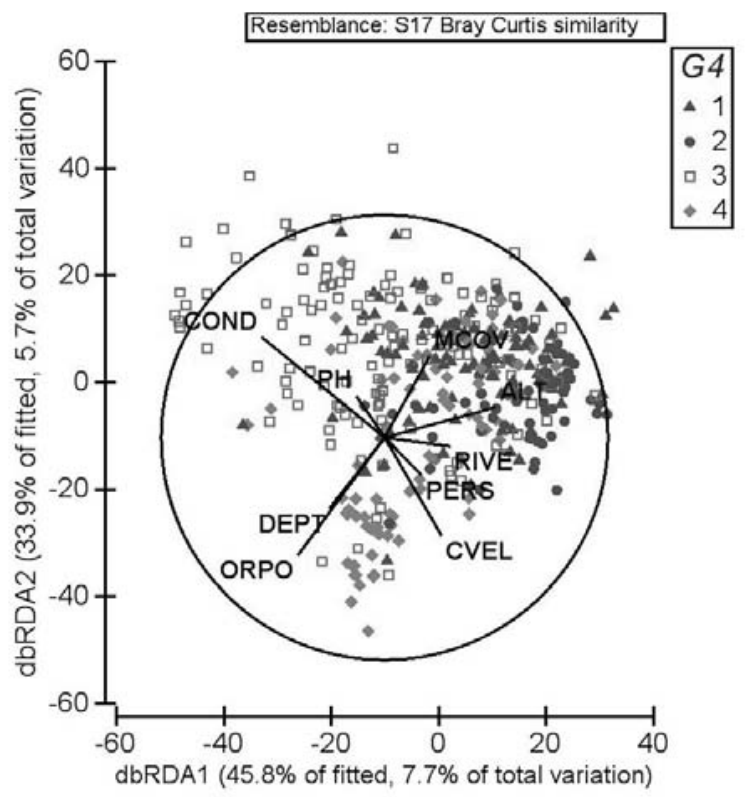

Figure 7. The dbRDA of sample sites classified by four groups (G4) as defined by the hierarchical clustering (see Fig. 2 for the group codes and Table 2 for environmental variable codes). Análisis de Redundancia basado en las distancias de las estaciones de muestreo clasificadas en 4 grupos (G4) definidos por la Clasificación Jerárquica (ver Fig. 2 para los códigos de los grupos y Tabla 2 para códigos de las variables ambientales).

\section{DISCUSSION}

The results of this study revealed the existence of four types of Hemipteran assemblages in the Segura River basin that corresponded primarily with lentic habitats (Groups 1, 3 and 4). However, ordination and classification patterns were partially obscured by the high mobility and low habitat requirements of Hemipterans. Hemipterans are homogeneous in faunistic and biological traits and environmental preferences (UsseglioPolatera et al., 2000; Mellado et al., 2008), which explains why approximately one-third of the species (13/38) displayed significant affinity for assemblage type. Of these 13 species, A. najas, A. cinereus, M. scholtzi, N. cinerea, $N$. maculatus and $N$. maculata displayed the highest habitat specificities.

Group 1 may be a transitional group distributed from the headwaters to the lower sec- tions of the Segura River basin with stagnant or low-flow environments in different lotic habitats. Group 1 was represented by indicator taxa such as $N$. cinerea, $N$. maculatus, $P$. minutissima, $N$. maculata and $M$. vittigera, which inhabit ponds and pools in different lotic habitats with varying conductivity, depth and macrophyte coverage (García-Avilés et al., 1996; Moreno et al., 1997; Usseglio-Polatera et al., 2000; Carbonell, 2010). The results from Group 2 (headwater streams) were consistent with previous studies that found A. najas and G. gibbifer to be frequent inhabitants of permanent mountain streams (Millán et al., 1988; 2002; García-Avilés et al., 1996). Corixids displayed lower indicator values due to a higher flight dispersal capability than other Hemipterans (Velasco \& Millan, 1998; Polhemus $\&$ Polhemus, 2008), and they also can colonise and withstand a wide range of environmental conditions, although they do display a preference for eutrophicated habitats. Some species were significant indicators in saline wetlands and pools (Group 3). Among these species, S. selecta often was collected in coastal and inland water bodies with a wide range of salinity (Barahona et al., 2005; Velasco et al., 2006). Within the Notonectidae family, A. sardeus was commonly found in artificial and lentic waters, such as irrigation pools (García-Avilés et al., 1996; Abellán et al., 2006). Group 4 included $A$. cinereus and M. scholtzi, which inhabit deep regions within the middle courses of impaired rivers and reservoirs (Millán et al., 1988; 2002).

In concordance with our hypothesis, multivariate relationships among the various Hemiptera assemblages and ecological factors demonstrated that the distribution of aquatic Hemiptera in the Segura River basin was influenced primarily by an environmental gradient from lotic and freshwater environments in headwaters to lentic and high-mineral waters in the lower sections. These results also were consistent with previous studies using collections in the same river basin that included other macroinvertebrate groups (Millán et al., 1996; 2006; Mellado, 2005). However, the correlation between environmental variables and aquatic Hemiptera was weak, and the ordination patterns also re- 
vealed a high degree of spatial dispersion of the four assemblage groups throughout the river basin, with the ecological and biological features of the Hemipteran species likely a contributing factor (Mellado et al., 2008). Although reachscale variables, such as salinity, current velocity and altitude, influence Hemiptera distribution, microhabitat availability (e.g., particular vegetation patches or backflows in a river reach with general high current velocity) in different habitat types also can influence the distribution of species with high mobility and low habitat specificity (Karaouzas \& Gritzalis, 2006; Pholemus \& Pholemus, 2008). Thus, some Hemipterans can easily colonise low-flow pools or backflows in stream and rivers reaches that are far apart from each other (Millán et al., 2002). On the other hand, aquatic Hemiptera species, in general, have a high dispersion capacity, as demonstrated by their migration when environmental characteristics become unfavourable (Nieser et al., 1994; Velasco \& Millán, 1998). Unfortunately, these characteristics complicate the interpretation of the spatial distribution of Hemipterans throughout the Segura River basin. These complications exist with other insect groups, such as the Dytiscidae family from the Coleoptera order, which often displays similar biological and ecological features to Hemipterans (Usseglio-Polatera et al., 2000; Mellado et al., 2008; Picazo et al., 2010).

In conclusion, the distribution of aquatic Hemiptera in the Segura River basin may be influenced by an environmental gradient from headwaters to lower river sections, and conductivity, current velocity and altitude appear to be the most significant contributing variables. Nevertheless, these findings suggest that the patterns observed in Hemiptera assemblages are likely determined not only by macroscale variables but also by microhabitat variables associated with their biological traits. Therefore, the integration of these habitat scales with biological trait information will be a crucial task in future studies to ensure a better understanding of the presence and distribution of this group of aquatic insects in Mediterranean regions.

\section{ACKNOWLEDGEMENTS}

We thank David Sánchez-Fernández, Félix Picazo and Paula Arribas for their help during several stages of this study. This work was supported by funding from two predoctoral FPU grants to J.A. Carbonell and D. Bruno. Funding for C. Gutiérrez-Cánovas and P. Abellán was provided by predoctoral and postdoctoral grants, respectively, from the Fundación Séneca (Murcia, Spain). We also want to thank the 'AIL' committee for awarding the poster based on this paper to be the best poster in the XV Congress of the 'AIL'.

\section{REFERENCES}

ABELLÁN, P., J. BARAHONA, D. SÁNCHEZFERNÁNDEZ, J. VELASCO \& A. MILLÁN. 2004. Coleópteros y heterópteros acuáticos con interés de conservación en el entorno de Calblanque. Actas del III Congreso de la Naturaleza de la Región de Murcia, 89-97.

ABELLÁN, P., D. SÁNCHEZ-FERNÁNDEZ, A. MILLÁN, F. BOTELLA, J. A. SÁNCHEZZAPATA \& A. GIMÉNEZ. 2006. Irrigation pools as macroinvertebrate habitat in a semi arid agricultural landscape (SE Spain). Journal of Arids Environments, 67: 255-269.

ABELLÁN, P., D. SÁNCHEZ-FERNÁNDEZ, J. VELASCO \& A. MILLÁN. 2005. Assessing conservation priorities for insects: status of water beetles in southeast Spain. Biological Conservation, 121: 79-90.

ALLAN, J. D. \& A. S. FLECKER. 1993. Biodiversity conservation in running waters. Bioscience, 43: 32-43.

ANDERSON, M. J., R. N. GORLEY \& K. R. CLARKE. 2008. PERMANOVA+ for PRIMER: Guide to Software and Statistical Methods. PRIMER-E, Plymouth.

BARAHONA, J., A. MILLÁN \& J. VELASCO. 2005. Population dynamics, growth and production of Sigara selecta (Fieber, 1848) (Hemiptera, Corixidae) in a Mediterranean hypersaline stream. Freswater Biology, 50: 2101-2113.

CLARKE, K. R. \& R. N. GORLEY. 2006. Primer v6: User Manual / Tutorial. PRIMER-E, Plymouth. 
CARBONELL, J. A. 2010. Los hemípteros acuáticos de la Cuenca del Río Segura. Estado del conocimiento, Patrones de distribución y conservación. Tesis de licenciatura. Facultad de Biología. Universidad de Murcia. 119 pp.

DUFRÊNE, M. \& P. LEGENDRE. 1997. Species assemblages and indicator species: the need for a flexible asymmetrical approach. Ecological Monographs, 67: 345-366.

FUENTE, J. M., DE LA. 1894. Insectos recogidos en Archena (Murcia). Actas de la Sociedad Española de Historia Natural, 26: 129-131.

GARCÍA-AVILÉS, J., M. A. PUIG \& A. G. SOLER. 1996. Dsitribution and associations of the aquatic Heteroptera of the Balearic Islands (Spain). Hydrobiologia, 324: 209-217.

GÓMEZ, R., I. HURTADO, M. L. SUÁREZ \& M. R. VIDAL-ABARCA. 2005. Ramblas in southeast Spain: threatened and valuable ecosystems. Aquatic Conservation: Marine and Freshwater Ecosystems, 15: 387-402.

GÓMEZ, A., P. A. TALAVERA \& R. VERDÚ. 1979. Contribución al conocimiento de los invertebrados en la zona de Revolcadores (W. Murcia). In: Comunicaciones sobre el Karst en la provincia de Murcia 2. Revolcadores. Servicio de Investigación y Defensa de la Naturaleza (ed.): 158-163. Diputación Provincial de Murcia, Murcia, España. 229 pp.

KARAOUZAS, I. \& K. C. GRITZALIS. 2006. Local and regional factors determining aquatic and semiaquatic bug (Heteroptera) assemblages in rivers and streams of Greece. Hydrobiologia, 573: 199212.

KRUSKAL, J. B. \& M. WISH. 1978. Multidimensional Scaling. SAGE Publications. Beverly Hills, California. $97 \mathrm{pp}$.

LELAND, H. V. \& S. V. FEND. 1998. Benthic invertebrate distribution in the San Joaquín River, California, in relation to physical and chemical factors. Canadian Journal of Fisheries and Aquatic Sciences, 55: 1051-1067.

MASTER, L. L., S. R. FLACK \& B. A. STEIN. 1998. Rivers of Life: Critical Watersheds for Protecting Freshwater Biodiversity. The Nature Conservancy: Arlington, VA. 71 pp.

MCCUNE, B. \& J. B. GRACE. 2002. Analysis of Ecological Communities. MjM Software Design. Gleneden Beach, Oregon. 300 pp.

MELLADO, A. 2005. The Ecology of Stream Macroinvertebrate Assemblages from the Segura
River Basin (SE Spain). Environmental factors, spatio-temporal variability, indicator taxa, diversity trends, biological-ecological traits and applications for bioassessment. $\mathrm{PhD}$ thesis. University of Murcia, Murcia, Spain. 200 pp.

MELLADO, A., M. L. SUÁREZ, J. L. MORENO \& M. R. VIDAL-ABARCA. 2002. Aquatic macroinvertebrate biodiversity in the Segura River basin (SE Spain). Verhandlungen des Internationalen Verein Limnologie, 28: 1157-1162.

MELLADO, A., M. L. SUÁREZ \& M. R. VIDALABARCA. 2008. Biological traits of stream macroinvertebrates from a semi-arid catchment: patterns along complex environmental gradients. Freshwater Biology, 53: 1-21.

MILLÁN, A., P. ABELLÁN, I. RIBERA, D. SÁNCHEZ-FERNÁNDEZ \& J. VELASCO. 2006. The Hydradephaga of the Segura basin (SE Spain): twenty five years studying water beetles. Monograph on Hydroadephaga. In memoriam of Prof. Franciscolo. Memorie della Società entomologica italiana, 85: 137-158.

MILLÁN, A., J. L. MORENO \& J. VELASCO. 2002. Estudio faunístico y ecológico de los coleópteros y heterópteros acuáticos y semiacuáticos de la provincia de Albacete. Instituto de Estudios Albacetenses. Albacete. 120 pp.

MILLÁN, A., J. VELASCO, N. NIESER \& C. MONTES. 1988. Heterópteros acuáticos (Gerromorpha y Nepomorpha) de la cuenca del río Segura, S. E. España. Anales de Biología, 15: 74-89.

MILLÁN, A., J. VELASCO \& A. SOLER. 1987. Claves gráficas para la identificación de los heterópteros acuáticos (Gerromorpha \& Nepomorpha) de la Cuenca del Río Segura. S. E. de la Península Ibérica. Anales de Biología, 11: 71-80.

MILLÁN, A., J. VELASCO, M. L. SUÁREZ, M. R. VIDAL-ABARCA \& L. RAMÍREZ-DÍAZ. 1996. Distribución espacial de los adephaga acuáticos (Coleoptera) en la Cuenca del Río Segura (SE de la península Ibérica). Limnetica, 12: 13-29

MORENO, J. L., D. G. ANGELER \& J. DE LAS HERAS. 2010. Seasonal dynamics of macroinvertebrate communities in a semiarid saline spring stream with contrasting environmental conditions. Aquatic Ecology, 44: 177-193.

MORENO, J. L., A. MILLÁN, M. L. SUÁREZ, M. R. VIDAL-ABARCA \& J. VELASCO. 1997. Aquatic Coleoptera and Heteroptera assemblages in waterbodies from ephemeral coastal streams 
("ramblas") of south-eastern Spain. Archiv für Hydrobiologie, 141: 93-107.

NIESER, N., M. BAENA, J. MARTÍNEZ-AVILÉS \& A. MILLÁN. 1994. Claves para la identificación de los heterópteros acuáticos (nepomorpha \& gerromorpha) de la Península Ibérica. Con notas sobre las especies de las Islas Azores, Baleares, $\mathrm{Ca}$ narias y Madeira. Asociación Española de Limnología. Madrid. 112 pp.

PICAZO, F., J. L. MORENO \& A. MILLÁN. 2010. The contribution of standing waters to aquatic biodiversity: the case of water beetles in southeastern Iberia. Aquatic Ecology, 44: 205-216.

POLHEMUS, J. T. \& D. A. POLHEMUS. 2008. Global diversity of true bugs (Heteroptera; Insecta) in freshwater. Hydrobiologia, 595: 379-391.

RICCIARDI, A. \& J. B. RASMUSSEN. 1999. Extinction rates in North American freshwater fauna. Conservation Biology, 13: 1220-1222.

SÁNCHEZ-FERNÁNDEZ, D., P. ABELLÁN, J. VELASCO \& A. MILLÁN. 2003. Los coleópteros acuáticos de la Región de Murcia. Catálogo faunístico y áreas prioritarias de conservación. Monografías SEA, vol. 10, Zaragoza. 70 pp.

SÁNCHEZ-FERNÁNDEZ, D., P. ABELLÁN, J. VELASCO \& A. MILLÁN. 2004. Selecting areas to protect the biodiversity of aquatic ecosystems in a semiarid Mediterranean region. Aquatic Conservation: Marine and Freshwater Ecosystems, 14: 465479.

SAUNDERS, D., J. MEEUWIG \& J. A. VINCENT.
2002. Freshwater protected areas: strategies for conservation. Conservation Biology, 16: 30-41.

SUÁREZ, M. L., M. R. VIDAL-ABARCA, C. MONTES \& A. G. SOLER. 1983. La calidad de las aguas del canal de desagüe de "El Regerón" (Río Guadalentín: Cuenca del Segura). Anales de la Universidad de Murcia. Vol. XLII. No 1-4. 201236.

USSEGLIO-POLATERA, P., M. BOURNAUD, P. RICHOUX \& H. TACHET. 2000. Biological and ecological traits of benthic freshwater macroinvertebrates: relationships and definition of groups with similar traits. Freshwater Biology, 43; 175205.

VELASCO, J. \& A. MILLÁN. 1998. Insect dispersal in a drying desert stream: effects of temperature and water loss. The Southwestern Naturalist, 43 (1): 80-87.

VELASCO, J., A. MILLÁN, J. HERNÁNDEZ, C. GUTIÉRREZ, D. SÁNCHEZ, P. ABELLÁN \& M. RUIZ. 2006. Response of biotic communities to salinity changes in a Mediterranean hypersaline stream. Saline Systems, 12: 1-15.

VELASCO, J., A. MILLÁN \& N. NIESER. 1990. Observaciones sobre la colonización y el ciclo de vida de Heliocorisa vermiculata (Puton, 1874) (Heteroptera, Corixidae) en pequeños estanques del se español. Limnetica, 6: 101-108.

VIDAL-ABARCA, M. R., M. L. SUÁREZ \& L. RAMÍREZ-DÍAZ. 1992. Ecology of Spanish semiarid streams. Limnetica, 8: 151-160. 